\title{
An active v-abl protein tyrosine kinase blocks immunoglobulin light-chain gene rearrangement
}

\author{
Yunn-Yi Chen, Li Chun Wang, Mary S. Huang, ${ }^{1}$ and Naomi Rosenberg ${ }^{2}$ \\ Immunology Graduate Program and Departments of Pathology and Molecular Biology and Microbiology, Tufts University \\ School of Medicine, Boston, Massachusetts 02111 ; and ${ }^{1}$ Department of Pediatric Hematology and Oncology, Dana Farber \\ Cancer Institute, Children's Hospital, Boston, Massachusetts 02115 USA
}

Lymphoid cells transformed by Abelson murine leukemia virus have provided one of the classic models for study of early B-cell development and immunoglobulin rearrangement. Most of these cells have rearranged their heavy-chain locus but not their light chain genes, suggesting that an active v-abl protein interferes with this differentiation step. To test this hypothesis, light-chain gene structure was examined in pre-B cells transformed by temperature-sensitive mutants of the Abelson virus and in derivatives that survive at the nonpermissive temperature because they express a human $B C L-2$ gene. Our studies reveal that inactivation of the $v-a b l$ protein tyrosine kinase triggers high-frequency rearrangement of $\kappa$ and $\lambda$ light-chain genes. These events are accompanied by marked increases in the expression of RAG-1 and RAG-2 RNAs. These increases occur in the absence of protein synthesis but are dependent on inactivation of the v-abl protein tyrosine kinase. As documented in the accompanying paper (Klug et al., this issue), an active v-abl protein also suppresses the activity of $\mathrm{NF}-\mathrm{kB} / \mathrm{rel}$ and expression controlled by the $\kappa$ intron enhancer. Together these data demonstrate that the $v-a b l$ protein specifically interferes with light-chain gene rearrangement by suppressing at least two pathways essential for this stage of B-cell differentiation and suggest that tyrosine phosphorylation is important in regulating RAG gene expression.

[Key Words: v-abl; protein tyrosine kinase; immunoglobulin gene rearrangement; RAG genes]

Received December 20, 1993; revised version accepted Janary 28, 1994.

Pre-B cells transformed by the v-abl oncogene of the Abelson murine leukemia virus (Ab-MuLV) have been the principal tumor model used to study immunoglobulin gene recombination (for review, see Rosenberg and Witte 1988; Schatz et al. 1992). As with their normal counterparts, most of the transformants have rearranged their heavy-chain locus and many express $\mu$ protein. However, unlike normal pre-B cells, the transformants appear frozen at the pre- $\mathrm{B}$ cell stage and do not rearrange light-chain genes or mature to surface immunoglobulin $M$ (IgM)-positive B cells. This failure is perplexing because the cells rearrange substrates containing recombination signal sequences, the recognition elements that mediate antigen receptor gene rearrangement (Lewis et al. 1984; Lieber et al. 1987). In addition, many of the transformants actively complete heavy chain gene assembly in culture, joining $V(H)$ to $D J(H)$ elements (Alt et al. 1984; Reth et al. 1986). Consistent with these features, the cells express both the RAG-1 and RAG-2 genes (Schatz et al. 1989; Oettinger et al. 1990), the products of which are absolutely required for antigen receptor gene assembly (Mombaerts et al. 1992; Shinkai et al. 1992).

${ }^{2}$ Corresponding author.
The phenotype of Ab-MuLV-transformed lymphoid cells suggests that transformation specifically interferes with light-chain gene rearrangement. This model predicts that the protein tyrosine kinase activity of the $\mathrm{v}-a b l$ protein affects the expression or function of at least one molecule that is required for this phase of rearrangement. Candidate targets could include transcription factors involved in the expression of the light-chain loci. Expression of the participating elements is tightly correlated with rearrangement (Yancopoulos and Alt 1985; Schlissel and Baltimore 1989; Oltz et al. 1993), and expression of the $\kappa$ locus is usually negligible in Ab-MuLV transformants (Schlissel and Baltimore 1989). Other targets could be factors that affect chromatin structure in the region (Engler et al. 1991, 1993; Jenuwein et al. 1993). Products required for all antigen receptor gene rearrangement, such as those encoded by the RAG-1 and RAG-2 genes (Schatz et al. 1989; Oettinger et al. 1990; Mombaerts et al. 1992; Shinkai et al. 1992), could also be affected. Little is known about the levels required to activate or sustain rearrangement and limiting amounts of one or both of these products could inhibit rearrangement at the light-chain loci.

We have tested the hypothesis that Ab-MuLV trans- 
formation blocks light-chain gene rearrangement using pre-B cells transformed by a temperature-sensitive $(t s)$ $\mathrm{Ab}-\mathrm{MuLV}$ transformation mutant (Engelman and Rosenberg 1987, 1990|. At the permissive temperature, these cells are similar to wild-type $(w t)$ transformants in differentiation parameters and express an active v- $a b l$ protein tyrosine kinase. At the nonpermissive temperature, the $\mathrm{v}-a b l$ kinase is inactive in ts transformants, and the cells undergo apoptosis (Chen and Rosenberg 1992). However, derivatives of the ts transformants that express a human $B C L-2$ gene (Hockenberry et al. 1990) survive at the nonpermissive temperature. A high frequency of these cells undergo light-chain gene rearrangement soon after shift to this temperature. Rearrangement is accompanied by increased expression of $R A G-1$ and RAG-2 RNAs, changes that occur coincident with the loss of $\mathrm{v}-a b l$ protein tyrosine kinase activity and do not require protein synthesis or elevated expression of $B C L$ 2. The accompanying paper (Klug et al., this issue) demonstrates that the $\mathrm{v}-a b l$ protein tyrosine kinase suppresses activation of $\mathrm{NF}-\mathrm{kB} / \mathrm{rel}$ and expression controlled by the $\kappa$ intron enhancer. Together, these data document the first instance in which high-frequency light-chain gene rearrangement can be triggered in a controlled fashion and implicate tyrosine phosphorylation as a central mechanism controlling expression of at least two pathways important for this differentiation event.

\section{Results}

BCL-2 allows survival of the ts transformants at the nonpermissive temperature

To facilitate analysis of the ts transformants, we asked whether $B C L-2$ would promote survival of the ts transformants at the nonpermissive temperature. Two $t s$ transformants, DE and 103, and a cell line transformed by wt Ab-MuLV (WT1) were transfected with pSFFVBCL-2nl, a vector that expresses the human $B C L-2$ gene and a neomycin resistance gene (Hockenberry et al. 1990). G418-resistant clones were selected and screened by Western blotting with an anti-human $B C L-2$ antibody (McDonnell et al. 1990) to identify those that expressed the introduced gene. All of the G418-resistant clones tested expressed the human $B C L-2$ protein (Fig. 1A; data not shown). The anti-human $B C L-2$ antibody did not react with proteins expressed by the parental cell lines or by cell lines that were transfected with a plasmid expressing only the neomycin resistance gene (Fig. 1A; data not shown).

To test the effect of $B C L-2$ expression on cell survival, the transfectants were shifted to the nonpermissive temperature, and cell number and viability were monitored (Fig. 1B). Unlike the parental ts cells or cells transfected with the control plasmid, $\sim 50 \%$ of the $t s$ cells expressing $B C L-2$ survived for $\geqslant 2$ weeks at the nonpermissive temperature. As expected, the cells remained in the $G_{1}$ phase of the cell cycle throughout this period /data not shown|, but resumed normal growth after shift back to the permissive temperature. Expression of human $B C L-2$
A

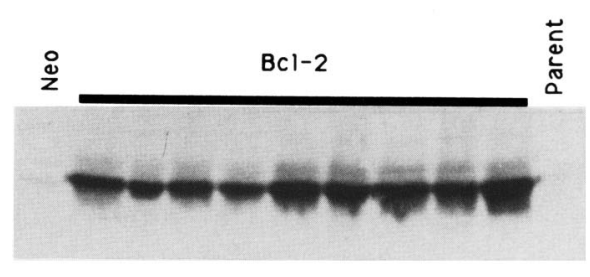

B

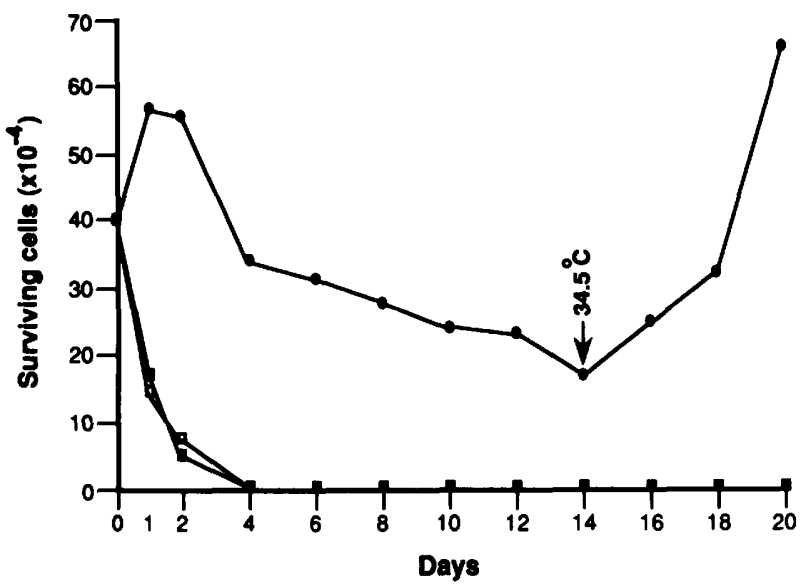

Figure 1. tstransformants overexpressing $B C L-2$ survive at the nonpermissive temperature. $(A)$ The ts transformant 103 was transfected with pSFFV-BCL-2nl, a plasmid expressing the human $B C L-2$ gene and a gene encoding neomycin resistance or a plasmid expressing neo only. G418-resistant clones were expanded and analyzed for expression of $B C L-2$ protein by using Western blotting (McDonnell et al. 1990). The blot was probed with the anti-human $B C L-2$ hamster monoclonal antibody $6 \mathrm{C} 8$. (Lane Neo) A representative clone transfected with the plasmid expressing only the neo gene; (lane Parent) 103 cells that were not transfected. $(B)$ A representative experiment in which a 103 clone expressing the introduced $B C L-2$ gene $(0)$, the parental 103 cells $(\square)$, and a 103 clone transfected with the neo plasmid (D) were plated at the nonpermissive temperature at a density of $4 \times 10^{5}$ cells $/ \mathrm{ml}$. Cell number and viability were monitored by trypan blue exclusion for 14 days. The cultures were then shifted to the permissive temperature and the experiment was continued for 6 days. The numbers shown are the averages of triplicate samples, which varied by $<10 \%$. This experiment is representative of identical analyses with three independently derived 103/BCL-2 clones; each cell line was evaluated at least twice.

had no effect on the growth or survival of $t$ s cells at the permissive temperature or on wt transformants maintained at either temperature (data not shown).

Recombinase activity is increased in the ts transformants at the nonpermissive temperature

The ability of cells to recombine recombination signal sequences is an indicator of an active recombinase system (Hesse et al. 1987, Lieber et al. 1987). To determine 
whether changes in the recombinase activity of the ts transformants occurred when the cells were maintained at the nonpermissive temperature, these cells and $w t$ transformants were tested by using extrachromosomal recombination substrates. These plasmid substrates carry the genes for ampicillin and chloramphenicol resistance, but the gene specifying chloramphenicol resistance is expressed only if recombination occurs. Thus, the frequency of plasmids recovered from cells that confer resistance to both drugs is a measure of recombinase activity (Hesse et al. 1987; Lieber et al. 1987). As expected, all of the transformants displayed recombinase activities typical of Ab-MuLV-transformed cells (Lieber et al. 1987; Ramakrishnan and Rosenberg 1988) when grown at the permissive temperature (Table 1). However, when the $t s$ cells were grown at the nonpermissive temperature, recombinase activities increased 4- to 11-fold. None of the wt transformants tested showed increased recombinase activity at the nonpermissive temperature. Although $B C L-2$ was used to maintain some of the $t s$ transformants at the nonpermissive temperature, expression of this gene was not required for the temperaturedependent increases in recombinase activity.

\section{High-frequency $\kappa$ light-chain gene rearrangement is activated at the nonpermissive temperature in the ts transformants}

The results of the recombinase assays suggested that dif- ferentiation-related changes might occur when the ts transformants are incubated at the nonpermissive temperature. As with most Ab-MuLV transformants (Alt et al. 1984), ts DE and 103 and wt WTl appear arrested at the pre-B cell stage and have nonproductive heavy-chain rearrangements (data not shown) and germ-line $\kappa$ and $\lambda$ light-chain genes. To determine whether incubation at the nonpermissive temperature released the differentiation arrest, the structure of the $\mathrm{\kappa}$ loci in the $B C L$-2-positive derivatives of 103 was compared with that found in representative WTl transformants by using Southern blotting. In this assay, fragments of a size distinct from germ line are scored as rearrangements. Because many different rearrangements occur in the population, multiple fragments of different sizes are usually detected. No $\kappa$ rearrangements were detected in the WT clones even after 11 days at the nonpermissive temperature (Fig. 2A; data not shown). However, multiple $\kappa$ rearrangements were visible in the 103-derived clones after as little as 24-48 $\mathrm{hr}$ at the nonpermissive temperature (Fig. 2B). Similar results were obtained with the ts DE cell line (data not shown).

PCR analyses, which detected rearrangements to the four functional $J(\kappa)$ elements, revealed a similar pattern and demonstrated that expression of $B C L-2$ was not required for $\kappa$ rearrangement (Fig. 2C). The low levels of $\kappa$ rearrangement detected in the $t s$ transformants at the permissive temperature and in the WT1 cell line (Fig.

Table 1. Recombinase activity is increased in ts cells incubated at the nonpermissive temperature

\begin{tabular}{|c|c|c|c|c|c|}
\hline Cell line & Temperature & $\begin{array}{l}\text { No. of } \\
\text { Amp }^{r} \text { colonies }\end{array}$ & $\begin{array}{l}\text { No. of } \\
\text { Amp }^{r} \text { Cam }^{r} \\
\text { colonies }\end{array}$ & $\begin{array}{l}\text { Recombinase } \\
\text { activity (R.A.) }\end{array}$ & $\begin{array}{l}\text { Fold increase } \\
\text { of R.A. }\end{array}$ \\
\hline \multirow[t]{2}{*}{ WT1 } & low & 17,725 & 591 & 2.33 & 1 \\
\hline & high & 12,660 & 190 & 1.50 & 0.64 \\
\hline \multirow[t]{2}{*}{ WT2 } & low & 34,508 & 1565 & 4.53 & 1 \\
\hline & high & 63,230 & 2910 & 4.60 & 1.01 \\
\hline \multirow[t]{2}{*}{ WT3 } & low & 10,854 & 1237 & 11.40 & 1 \\
\hline & high & 8,583 & 568 & 6.62 & 0.58 \\
\hline \multirow[t]{2}{*}{ WT4 } & low & 19,274 & 594 & 3.08 & 1 \\
\hline & high & 11,074 & 68 & 0.61 & 0.2 \\
\hline \multirow[t]{2}{*}{ DF } & low & 4,530 & 377 & 8.32 & 1 \\
\hline & high & 1,737 & 736 & 42.37 & 5.1 \\
\hline \multirow[t]{2}{*}{$\mathrm{O}$} & low & 4,484 & 377 & 7.98 & 1 \\
\hline & high & 194 & 67 & 36.08 & 4.5 \\
\hline \multirow[t]{2}{*}{103} & low & 20,863 & 1194 & 5.72 & 1 \\
\hline & high & 4,204 & 1083 & 25.76 & 4.5 \\
\hline \multirow[t]{2}{*}{ WT1/BCL-2/1 } & low & 3,636 & 55 & 1.51 & 1 \\
\hline & high & 4,595 & 71 & 1.43 & 0.9 \\
\hline \multirow[t]{2}{*}{ DE/BCL-2/1 } & low & 6,673 & 653 & 9.79 & 1 \\
\hline & high & 12,887 & 4644 & 36.04 & 3.7 \\
\hline \multirow[t]{2}{*}{ 103/BCL-2/1 } & low & 37,989 & 1570 & 4.13 & 1 \\
\hline & high & 12,848 & 6059 & 47.16 & 11.4 \\
\hline \multirow[t]{2}{*}{ 103/BCL-2/13 } & low & 23,288 & 1013 & 4.35 & 1 \\
\hline & high & 15,233 & 4950 & 32.50 & 7.5 \\
\hline
\end{tabular}

Recombinase assays were conducted as described in Materials and methods. The values given represent the sum of two experiments in which similar results were obtained. The cell lines WT1, WT2, WT3, and WT4 are transformed with wt Ab-MLV; the cell lines DE, $\mathrm{O}, \mathrm{DF}$, and 103 are transformed by ts Ab-MuLV. WT1/BCL-2/1, DE/BCL-2/1, 103/BCL-2/1 and 103/BCL-2/13 are independently derived subclones of WT1, DE and 103 that express the human BCL- 2 gene. Low temperature refers to $34^{\circ} \mathrm{C}$; High temperature refers to $39.5^{\circ} \mathrm{C}$. 


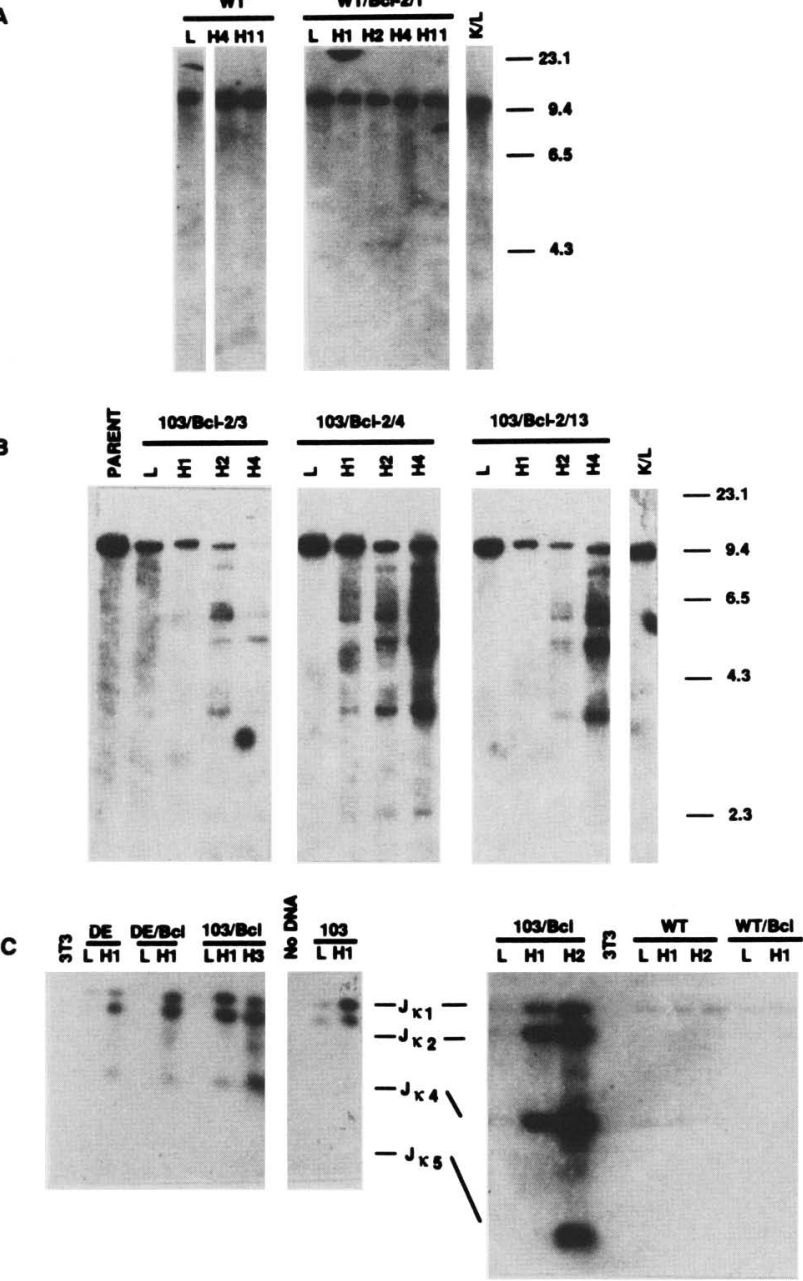

Figure 2. $\kappa$ rearrangement is activated at the nonpermissive temperature in $t s$ transformants. (A) DNAs prepared from a $w t$ (WT) transformant and a derivative expressing the human $B C L-2$ gene (WT/Bcl-2/1) were digested with $B a m H I$ and analyzed with a $C \kappa$ probe. $(B)$ DNAs prepared from the $t s$ transformant 103 (PARENT) and three $B C L-2$ derivatives (103/Bcl-2) were analyzed for $\kappa$ rearrangement as described in $A$. (K/L) DNA from normal kidney and liver. $(C)$ The $t s$ transformants $D E$ and 103 and the wt transformant WT1 and derivatives expressing $B C L-2$ were analyzed for $\kappa$ rearrangements by using PCR /see Materials and methods). (No DNA) A control reaction containing no cellular DNA; (3T3) DNA from NIH-3T3 cells transformed with $\mathrm{Ab}-\mathrm{MuLV}$; In all panels, $\mathrm{L}$ indicates permissive temperature; $(\mathrm{H})$ nonpermissive temperature. The number after the $\mathrm{H}$ designates the days at the nonpermissive temperature. Sizes are indicated in kilobases.

2C) are similar to those observed in many Ab-MuLVtransformed cells lines (Schlissel and Baltimore 1989; Shapiro et al. 1993; Y. Chen et al., unpubl.). Importantly, this level did not change when wt transformants were incubated at the nonpermissive temperature. Although $39.5^{\circ} \mathrm{C}$ is the standard nonpermissive temperature used with the $t s \mathrm{Ab}-\mathrm{MuLV}$ mutants, inactivation of the $\mathrm{v}-a b l$ protein tyrosine kinase activity and activation of $\kappa$ rear- rangement occur at $37^{\circ} \mathrm{C}$ (not shown). Thus, neither expression of $B C L-2$ nor incubation at what might be considered an abnormally high temperature is required to activate high levels of $\kappa$ rearrangement.

\section{Rearrangements involving $\kappa$ and $\lambda$ genes and $R S$ sequences occur at the nonpermissive temperature}

In addition to rearranging the $\kappa$ locus, $B$-lineage cells can rearrange the $\lambda$ light-chain locus and sequences $3^{\prime}$ of $C_{k}$ called RS (Durdik et al. 1984; Graninger et al. 1988). To examine the frequency of cells that underwent such rearrangements at the nonpermissive temperature, the 103/BCL-2/4 clone was shifted to the nonpermissive temperature for 4 days, shifted back to the permissive temperature, and subcloned. DNAs from these clones were examined by Southern blotting, an assay that reveals rearrangements as fragments that are distinct in size from the unrearranged or germ-line fragment characteristic of nonlymphoid cells. All but 2 of the 18 subclones analyzed had undergone rearrangement involving at least one of these sequences (Fig. 3). Rearrangements involving the $\kappa$ locus occurred in 15 clones. In most of these cases, germ-line sequences were no longer detected. Rearrangements involving the $\lambda$ locus were detected in 6 clones, and 13 had rearranged their RS sequences. Of the 15 clones that had rearranged the $\kappa$ locus, 13 had rearranged both $\kappa$ alleles; at least 4 of these subclones showed evidence of both RS and $\lambda$ rearrangements. None appeared to be rearranged only at the $\lambda$ locus. Analyses of the structure of the T-cell receptor $\beta$ locus revealed that none of the clones had rearranged these sequences (data not shown), demonstrating that the recombinase machinery retained lineage fidelity at the nonpermissive temperature. Consistent with the analysis of bulk populations, examination of a panel of 103/BCL-2/4 subclones derived after continuous growth at the permissive temperature revealed that only 1 of 30 $\kappa$ alleles had undergone rearrangement (data not shown). Thus, incubation at the nonpermissive temperature triggers high-frequency rearrangement of all light-chain loci.

\section{RAG-1, RAG-2, and $\kappa$ expression increase with $v$-abl inactivation}

The tyrosine kinase activity of the $\mathrm{v}-a b l$ protein is reduced when the $t s$ transformants are incubated at the nonpermissive temperature (Engelman and Rosenberg 1990; Chen and Rosenberg 1992). To determine whether this decrease correlated with differentiation-related changes, the temporal relationship between reduced cellular phosphotyrosine and the expression of RAG-1, $R A G-2$, and $\kappa$ RNAs, three markers associated with rearrangement (Schlissel and Baltimore 1989; Lennon and Perry 1990; Oettinger et al. 1990|, was examined. Decreases in cellular phosphotyrosine could be detected between 4 and $6 \mathrm{hr}$ after shift to the nonpermissive temperature (Fig. 4). Increases in the levels of RAG-1 and RAG-2 RNAs appeared at this time, rising to levels that were 10 - to 20 -fold higher than those found in cells 

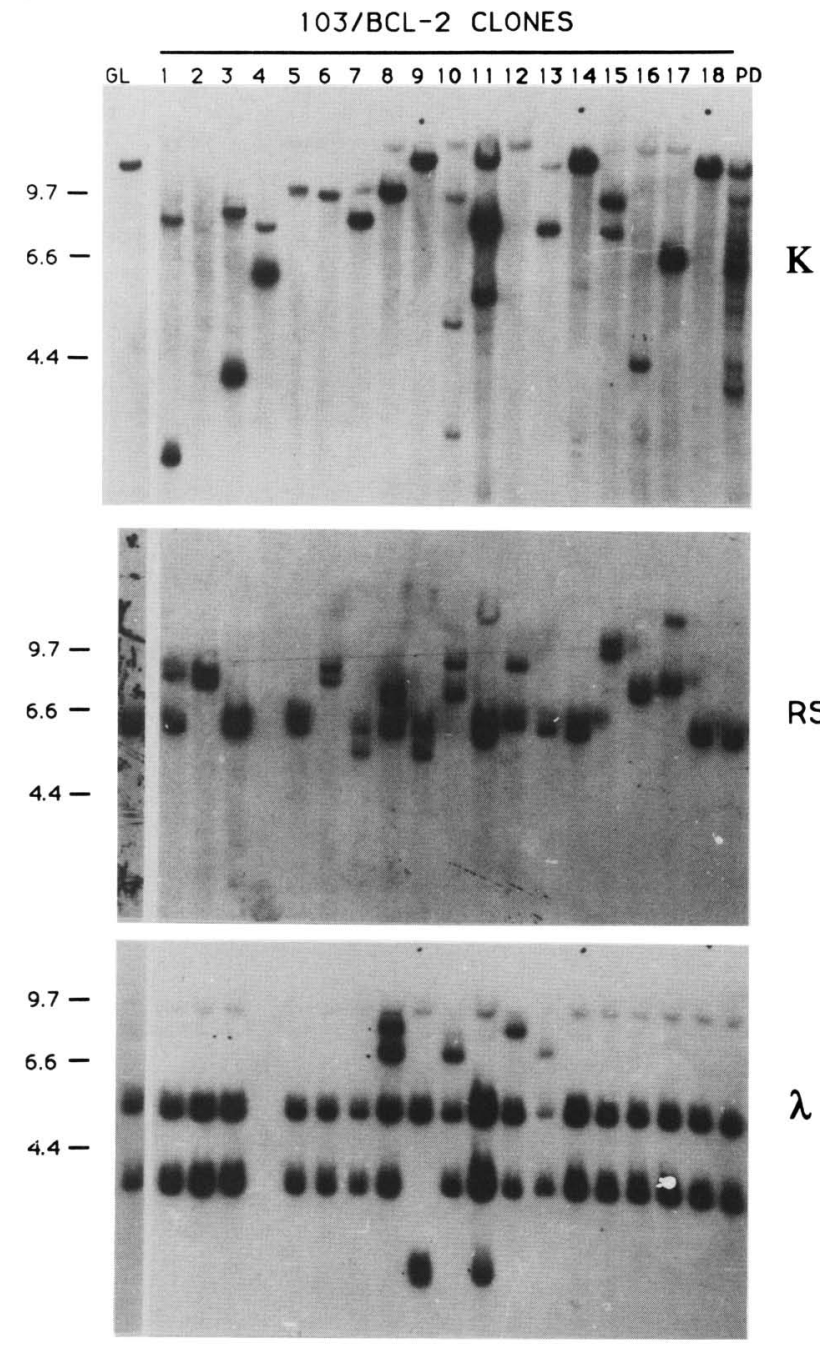

Figure 3. Many $\kappa$, RS, and $\lambda$ rearrangements occur at the nonpermissive temperature. $103-B C L-2 / 4$ cells were maintained at the nonpermissive temperature for 4 days and then shifted to the permissive temperature and subcloned. Southern blots of DNAs prepared from these clones were analyzed with probes for the $\kappa$ and $\lambda$ loci and RS. BamHI digestion was used for analysis of $\kappa ; E c o$ RI digestion was used for $\lambda$ and RS. In these last two blots, lane 4 does not contain DNA. (GL) Germ-line configuration as revealed by analysis of DNA from kidney and liver; (PD) the $\kappa$ rearranging $w t$ transformant $P D-31 / 300-18$ (Lewis et al. 1982). Sizes are indicated in kilobases.

maintained at the permissive temperature. Germ-line $\kappa$ RNAs also appeared as $\mathrm{v}-a b l$ protein kinase activity decreased (Fig. 4). These molecules could not be detected reproducibly by Northern blotting in samples from cells maintained at the permissive temperature. Similar results were obtained with several other independently derived $t s$ transformants.

The $t s$ transformants are arrested in the $G_{1}$ phase of the cell cycle at the nonpermissive temperature, a condition that could affect the levels of RAG RNAs. To examine this issue, $t s$ cells were synchronized at the permissive temperature and the levels of $R A G$ RNAs were examined in cells in early $G_{1}$ and in cells at the $\mathrm{G}_{1}$ /S boundary (Fig. 5). As expected for cells in $\mathrm{G}_{1}$ (Matsushime et al. 1991), these samples contained increased levels of $\mathrm{G}_{1}$-cyclin 2 RNA. However, no increases were observed in the levels of RAG RNAs. In addition, when $t s$ cells maintained at the nonpermissive temperature were shifted back to the permissive temperature, levels of $R A G$ RNAs decreased before significant numbers of cells exited $G_{1}$ (Fig. 5; data not shown). These data indicate that inactivation of $\mathrm{v}-a b l$ protein tyrosine kinase is a critical factor in stimulating light-chain gene rearrangement in the $t s$ pre-B cells.

\section{Increases in levels of RAG RNAs occur in the absence of protein synthesis}

To probe the mechanism by which v- $a b l$ inactivation induces the dramatic changes in RAG RNA levels, the stability of RAG-1 and RAG-2 RNAs at the permissive and nonpermissive temperatures was examined. $t s$ 103/ BCL-2 cells were shifted to the nonpermissive temperature for $20 \mathrm{hr}$ and then actinomycin D was added to these cells and to a parallel culture that had been maintained at the permissive temperature. As expected, much higher levels of RAG RNAs were recovered from the samples maintained at the nonpermissive temperature
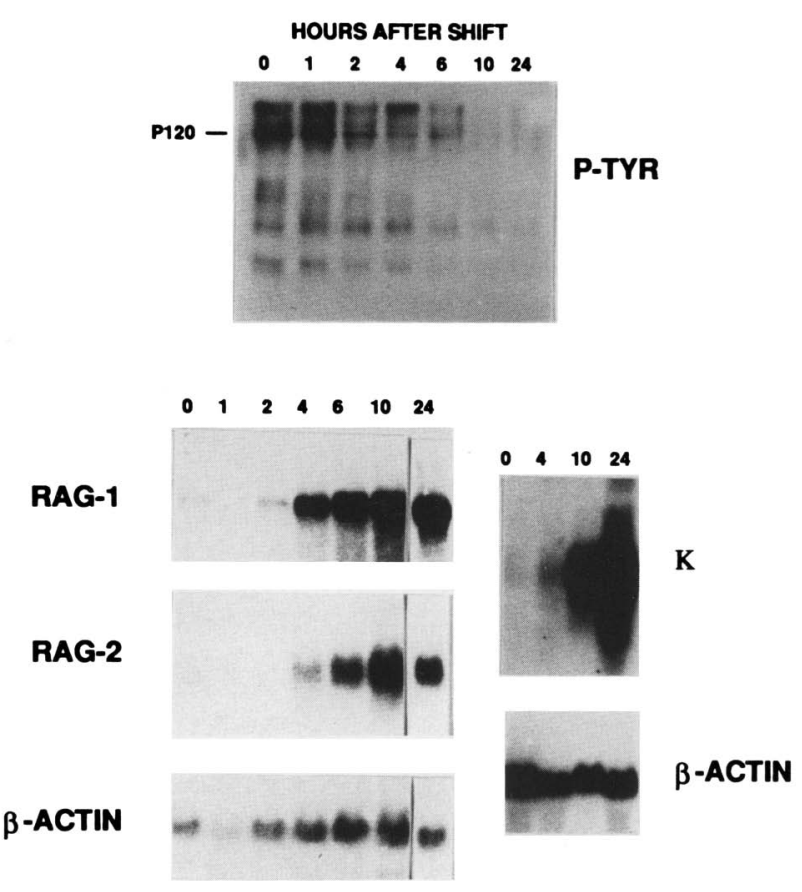

Figure 4. Increases in RAG and $\kappa$ RNAs correlate with loss of $v$ - $a b l$ function. (Top) Cell lysates from the $t s$ cell line 103/BCL$2 / 4$ were analyzed on Western blots probed with anti-phosphotyrosine antibody. The position of the P120 v- $a b l$ protein is indicated. (Bottom) RNAs were prepared from the cells and Northern blots were analyzed with probes for RAG-1, RAG-2, $C_{K}$, and $\beta$-actin. The times at the top of the lanes indicate hours after shift to the nonpermissive temperature. 

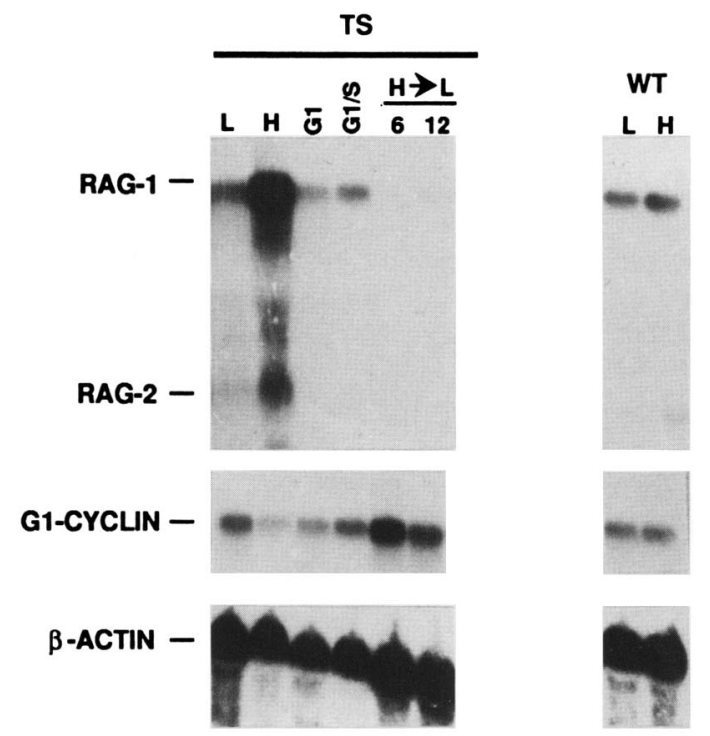

Figure 5. Increased expression of RAG RNAs is not a cell cycle-regulated effect. RNAs prepared from synchronized populations were analyzed with probes for $R A G-1, R A G-2, \mathrm{G}_{1}-$ cyclin 2 , and $\beta$-actin. RNAs from cells maintained at the nonpermissive temperature were harvested after incubation for $20 \mathrm{hr}$. Early $G_{1}$ cells were prepared by growing the cells in nocodazole at the permissive temperature for $16 \mathrm{hr}$ (Chen and Rosenberg 1992). The cells were washed and replated in fresh medium for $3 \mathrm{hr}$ and RNA was harvested. Cells at the $\mathrm{G}_{1} / \mathrm{S}$ boundary were treated with $1 \mathrm{mM}$ hydroxyurea for $16 \mathrm{hr}$. (TS) ts transformant $D E_{\text {; }}$ (WT) wt transformant, WT-1; (L) permissive temperature; $(\mathrm{H})$ nonpermissive temperature; $(\mathrm{H} \rightarrow \mathrm{L})$ cells maintained at the nonpermissive temperature for $20 \mathrm{hr}$, then shifted to the permissive temperature and harvested 6 or $12 \mathrm{hr}$ later.

(Fig. 6). However, densitometric analyses of multiple experiments revealed that the half-life of RAG-1 RNA was $\sim 45-60 \mathrm{~min}$ at both temperatures. The half-life of RAG-2 RNA was $\sim 30 \mathrm{~min}$ at the permissive temperature and $\sim 45-60 \mathrm{~min}$ at the nonpermissive temperature. Similar ranges have been observed by others using B-lineage cells (Ma et al. 1992). These data suggest that increased expression of RAG RNAs is mediated largely at the transcriptional level and imply that tyrosine phosphorylation is important in controlling the expression of these genes.

The time-course experiments demonstrate that changes in $R A G$ RNA expression are detected soon after shift to the nonpermissive temperature. To understand the steps involved in this process, we asked whether protein synthesis was required for increased expression of RAG-1 and RAG-2 RNAs. Analysis of cells treated with cycloheximide revealed that RAG-1 and RAG-2 RNA levels increased in the absence of protein synthesis (Fig. 7). Importantly, this increase was observed only at the nonpermissive temperature, reinforcing the role of $\mathrm{v}-a b 1$ protein inactivation in the process. Cells maintained at the permissive temperature in the presence of cycloheximide for the times shown retain an active v- $a b l$ protein because of the relatively long half-life of this molecule (data not shown). When considered in the context of the time course and actinomycin D experiments, these data suggest that the $\mathrm{v}-a b l$ protein tyrosine kinase mediates down-regulation of $R A G-1$ and $R A G-2$ gene expression in a fairly direct fashion.

\section{Discussion}

Our data demonstrate that an active $\mathrm{v}-a b l$ protein interferes with immunoglobulin light-chain gene rearrangement in transformed pre-B cells, providing a mechanistic explanation for the phenotype of most Ab-MuLV-transformed lymphoid cells. This property of $\mathrm{v}-a b l$ may play an important role in tumorigenesis in vivo. During this multistep process (Green et al. 1989), v-abl-stimulated precursors would be refractory to control mechanisms that regulate normal B-cell growth because they fail to rearrange light-chain genes and express IgM. A similar
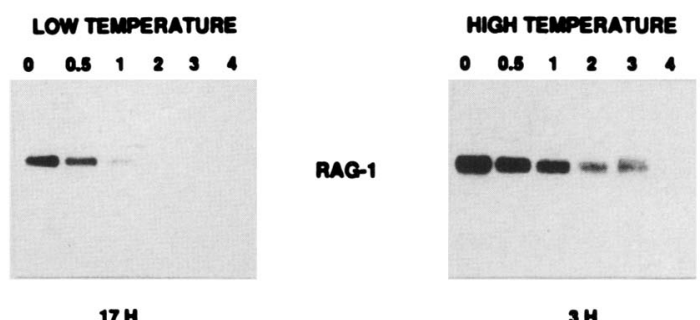

3H
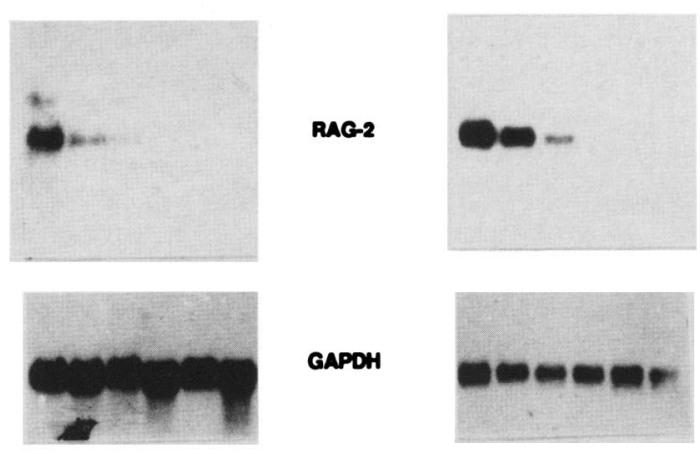

Figure 6. $R A G-1$ and $R A G-2$ RNAs are equally stable at the permissive and nonpermissive temperature. 103/BCL-2 cells were treated with $10 \mu \mathrm{g} / \mathrm{ml}$ of actinomycin D, and RNAs harvested at times thereafter were analyzed by Northern blotting using $R A G-1, R A G-2$, and glucose-6-phosphate dehydrogenase (GAPDH) probes. For the high-temperature samples, the cells were maintained at the nonpermissive temperature for $20 \mathrm{hr}$ before the addition of actinomycin $\mathrm{D}$ and incubated at this temperature during the experiment. For the low-temperature samples, the cells were maintained continuously at the permissive temperature. The numbers above the lanes indicate hours after the addition of actinomycin D. Because much higher levels of RAG RNAs are recovered from cells maintained at the nonpermissive temperature, the autoradiograph of the high-temperature samples was exposed for $3 \mathrm{hr}$; the low-temperature samples were exposed for $17 \mathrm{hr}$. Densitometric analyses were performed on autoradiographs exposed for various lengths of time to determine the half-lives of the RNAs. $\mathrm{G}_{1}$-arrested Ab-MuLV transformants express lower levels of GAPDH than exponentially growing transformants. 
Chen et al.

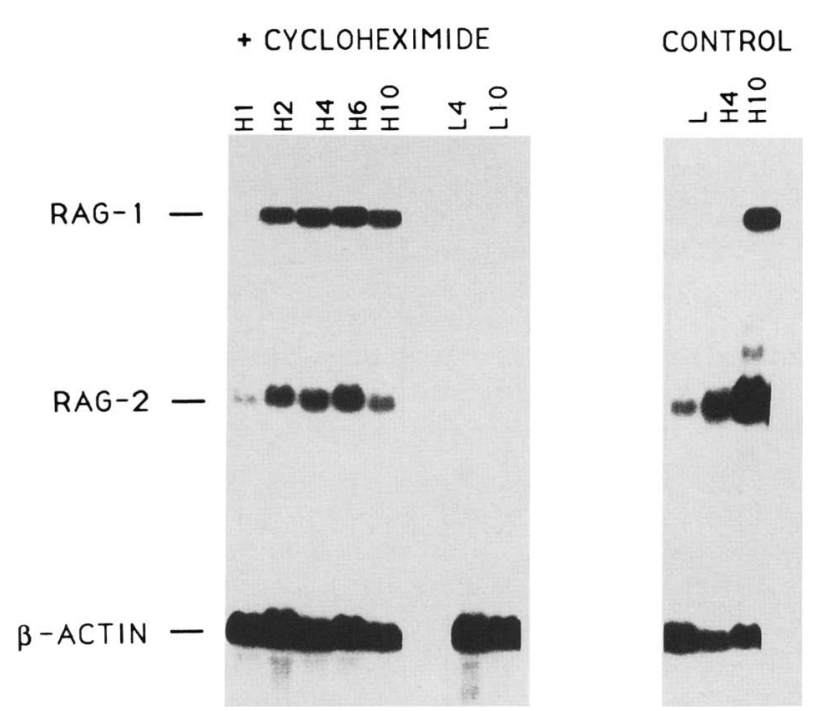

Figure 7. Protein synthesis is not required for upregulation of RAG RNAs. ts 103 cells were treated with $10 \mu \mathrm{g} / \mathrm{ml}$ of cycloheximide or sham-treated and incubated at the permissive and nonpermissive temperatures, and RNAs were prepared at multiple time points. Northern blots were analyzed with $R A G-1$, $R A G-2$, and $\beta$-actin probes. (L) Permissive temperature; $(\mathrm{H})$ nonpermissive temperature. The numbers above the lanes indicate hours of incubation.

phenomenon may play a role in BCR-ABL-positive acute lymphocytic leukemias (Sawyers et al. 1991). Data presented in the accompanying paper (Klug et al., this issue) reveal that the $\mathrm{v}-a b l$ protein tyrosine kinase suppresses $\mathrm{NF}-\mathrm{kB} / \mathrm{rel}$ activity. This response may modulate the differentiation of other hematopoietic target cells such as the pluripotent hematopoietic stem cells and immature $\mathrm{T}$ cells. The basic idea that the phenotype of transformants can be explained by effects of the $a b l$ protein tyrosine kinase on products that control differentiation almost certainly applies to these situations.

Expression of the human $B C L-2$ gene prolonged the survival of the ts transformants at the nonpermissive temperature. The response of the $t s$ cells is similar to that observed with a variety of hematopoietic cells (Vaux et al. 1988; Hockenberry et al. 1990; Nunez et al. 1990; Rolink et al. 1993). Most Ab-MuLV transformants, as with normal pre-B cells (Li et al. 1993), express low to undetectable levels of endogenous $B C L-2$ RNAs at both the permissive and nonpermissive temperature (M.S. Huang and N. Rosenberg, unpubl.). Presumably, these low levels are not sufficient to rescue the cells. Although $B C L-2$ expression was very useful for prolonging cell survival, we could find no evidence that it played a direct role in any of the differentiation events observed.

Light-chain rearrangement in the $t s$ cells occurs while the cells are arrested in $G_{1}$ (Chen and Rosenberg 1992). This situation may mimic that observed in normal cells because at least some normal pre-B cells are resting when light-chain gene rearrangement occurs (Hardy et al. 1991; Rolink et al. 1993). However, withdrawal from the cell cycle is probably not required to trigger differentiation-related events. Increased levels of $R A G$ RNAs can be detected within 4-6 hr after shift to the nonpermissive temperature. At this time point, $<10 \%$ of the population has undergone $G_{1}$ arrest (Chen and Rosenberg 1992). In addition, when $t s$ cells maintained at the nonpermissive temperature are shifted back to the permissive temperature, the level of RAG RNAs returns to baseline within $4-6 \mathrm{hr}$, although the cells have not exited $G_{1}$. Our data do not exclude a role for cell cyclemediated changes in RAG-1 or RAG-2 protein function. However, they do indicate that the changes in phosphorylation of $R A G-2$ protein postulated to occur at the $\mathrm{G}_{1} / \mathrm{S}$ border (Lin and Desiderio 1993) are not required to stimulate rearrangement.

One pathway important for $\mathrm{v}-a b l$-mediated differentiation arrest involves suppression of the $\kappa$ intron enhancer (Klug et al., this issue). This element is critical for $\kappa$ rearrangement (Takeda et al. 1993). The active $v-a b l$ protein exerts its effect on the $\kappa$ intron enhancer by suppressing NF- $\mathrm{kB} / \mathrm{rel}$ through a post-translational mechanism that increases the stability of $I_{\kappa} B \alpha$ (Klug et al., this issue). Consistent with these effects, inactivation of the $\mathrm{v}-a b l$ protein kinase triggers expression of $\mathrm{\kappa}$ RNAs, an event long correlated to $\mathrm{K}$ rearrangement in a variety of systems (Atchison and Perry 1987; Lenardo et al. 1987; Schlissel and Baltimore 1989; Lennon and Perry 1990). The specific relationship of these effects to $k$ rearrangement is consistent with the observation that most AbMuLV transformants contain an active recombinase system (Lieber et al. 1987; Ramakrishnan and Rosenberg 1988), and many actively rearrange the heavy-chain locus in vitro (Alt et al. 1984; Reth et al. 1986). This latter rearrangement event is correlated to expression of both germ-line $V(H)$ and $D J(H)$ segments, common properties of Ab-MuLV transformants that are not mediated by NFкB (Alt et al. 1982; Yancopoulos and Alt 1985; Lenardo and Baltimore 1989).

A second response to the loss of $\mathrm{v}-a b 1$ protein tyrosine kinase is increased expression of the RAG-1 and RAG-2 genes. These increases occur in the absence of protein synthesis suggesting that the v- $a b l$ protein affects expression of these genes in a fairly direct fashion. NF-кB/ rel probably does not mediate this effect. These factors can be activated by inhibiting protein synthesis in the presence of an active v- $a b$ l protein (Sen and Baltimore 1986; Klug et al., this issue), whereas increased $R A G$ expression requires an inactive $\mathrm{v}-a b l$ protein. Because there is little evidence that $\mathrm{v}-a b l$ protein is present in the nucleus, it seems more likely that factors that regulate $R A G$ expression are regulated negatively by $\mathrm{v}-a b l$-mediated tyrosine phosphorylation. Virtually nothing is known about the transcriptional regulation of the $R A G$ genes. Thus, identifying these candidate $\mathrm{v}-a b l$ targets will require considerable effort. Nonetheless, RAG gene expression is tightly regulated during lymphoid differentiation, and it is tempting to speculate that tyrosine phosphorylation, mediated by one or more of the protein tyrosine kinases expressed during $\mathrm{T}$ - and B-cell differentiation (Perlmutter et al. 1993), plays a key role in regu- 
lating these genes. Consistent with this hypothesis, overexpression of the lck protein tyrosine kinase has been shown to inhibit rearrangement of the T-cell receptor $\beta$ genes (Anderson et al. 1992).

The high level of RAG-1 and RAG-2 RNA expression, reflected in increased levels of both proteins (M.S. Huang, Y.Y. Chen., W.-C. Lin., S. Desiderio, and N. Rosenberg, unpubl.), is probably responsible for the dramatic increases in recombinase activity found at the nonpermissive temperature. High levels of these proteins may be required to trigger light-chain rearrangement in the majority of transformants in the population. This idea is consistent with the fact that $\mathrm{k}$ rearrangement occurs only at low levels in wt transformants even when lipopolysaccharide treatment activates NF-кB/rel and expression of germ-line $\kappa$ RNAs (Schlissel and Baltimore 1989|. It is likely that changes in both the $\kappa$ locus and the levels of $R A G$ are important for rearrangement and that $\mathrm{v}$-abl-mediated effects on both of these control points work together to suppress rearrangement. Consistent with this idea, expression of the RAG genes induces rearrangement of neither endogenous immunoglobulin genes in cells such as NIH-3T3 (Oettinger et al. 1990) or recombination substrates that are not expressed /Oltz et al. 1993).

An important feature of the $t s$ transformants is that inactivation of $\mathrm{v}-a b l$ not only triggers rearrangement of $\mathrm{k}$ but also RS and $\lambda$ sequences. Increased expression of $R A G-1$ and $R A G-2$ and activation of NF- $\mathrm{BB} / \mathrm{rel}$ and the $\mathrm{\kappa}$ intron enhancer are almost certainly important for these events. Because inhibition of protein synthesis alone does not up-regulate $R A G$ expression but can induce some activation of NF- $\mathrm{kB} / \mathrm{rel}$, at least two signaling pathways are probably involved in these events. Other events may be important as well. Activation of NF- $\mathrm{kB} /$ $r e l$ and expression of germ-line $\kappa$ RNAs is not sufficient for high-frequency $\kappa$ rearrangement (Schlissel and Baltimore 1989; Klug et al., this issue). In addition, there is no evidence to suggest that NF- $\mathrm{KB} / r e l$ is involved in rearrangement of $\lambda$ sequences (Hagman et al. 1990) and $k$ rearrangement is not absolutely required for $\lambda$ rearrangement (Chen et al. 1993; Zou et al. 1993). Thus, additional important regulatory elements may remain to be identified. The $t s$ transformants should provide a powerful system for the identification of such factors.

\section{Materials and methods \\ Cell culture}

The ts Ab-MuLV transformants DE, 103, DF, and O were transformed using the Ab-MuLV-P120/G+H strain and the wt AbMuLV transformants WT1, WT2, WT3, and WT4 were transformed using Ab-MuLV-P120 or Ab-MuLV-P160 (Engelman and Rosenberg 1990). All cells were grown routinely at $34^{\circ} \mathrm{C}$, the permissive temperature for the $t s \mathrm{Ab}-\mathrm{MuLV}$ mutants. The nonpermissive temperature used in all experiments was $39.5^{\circ} \mathrm{C}$. To obtain transfectants expressing the human $B C L-2$ gene, $8 \times 10^{6}$ cells were electroporated $(250 \mathrm{~V}, 960 \mu \mathrm{F}$ in a Bio-Rad Gene Pulsar) in the presence of $5 \mu \mathrm{g}$ of Sall-linearized spleen focusforming virus (SFFV)-BCL-2nl (Hockenberry et al. 1990). After
$48 \mathrm{hr}, 1.5 \mathrm{mg} / \mathrm{ml}$ of G418 was added to the cultures; individual clones of G418-resistant cells were isolated 14-21 days later. The transfectants were maintained in standard growth medium (Engelman and Rosenberg 1990) supplemented to contain $1 \mathrm{mg} /$ $\mathrm{ml}$ of G418. To derive subclones that had been exposed to the nonpermissive temperature, the $103 / \mathrm{BCL}-2 / 4$ clone was shifted to $39.5^{\circ} \mathrm{C}$ for 4 days and then shifted back to $34^{\circ} \mathrm{C}$. Two days later, the cells were plated in microtiter wells at a density of 0.3 , 1 , and 3 cells/well. After 3-5 days, wells that contained single clones of growing cells were identified by inspecting the cultures under a microscope. Cells in these wells were expanded.

\section{Drug treatments}

To obtain cell populations synchronized in early $\mathrm{G}_{1}$, cells were treated with $0.05 \mathrm{mg} / \mathrm{ml}$ of nocodazole and released as described previously (Chen and Rosenberg 1992). To obtain cell populations arrested at the $\mathrm{G}_{1} / \mathrm{S}$ interface, exponentially growing cells were treated with $1 \mathrm{~mm}$ hydroxyurea (Chen and Rosenberg 1992). Cell cycle analyses were conducted as described elsewhere (Chen and Rosenberg 1992) and confirmed that all synchronized populations displayed the anticipated pattern. For experiments using actinomycin $\mathrm{D}$, ts cells maintained continuously at $34^{\circ} \mathrm{C}$ and a sister culture maintained for $20 \mathrm{hr}$ at $39.5^{\circ} \mathrm{C}$ were used. Both populations were treated with $10 \mu \mathrm{g} / \mathrm{ml}$ of actinomycin $\mathrm{D}$, returned to $39.5^{\circ} \mathrm{C}$ or $34^{\circ} \mathrm{C}$ incubators, and sampled at intervals thereafter. For experiments using cycloheximide, cells maintained continuously at $34^{\circ} \mathrm{C}$ were treated with $10 \mu \mathrm{g} / \mathrm{ml}$ of cycloheximide, incubated at either $34^{\circ} \mathrm{C}$ or $39.5^{\circ} \mathrm{C}$, and sampled at intervals thereafter.

\section{Western blotting}

Cell lysates for analysis of $B C L-2$ expression were prepared as described (McDonnell et al. 1990). The amount of protein in each lysate was quantitated using the BCA protein assay kit (Pierce), and $100 \mu \mathrm{g}$ of each sample was fractionated through a $12.5 \%$ SDS-polyacrylamide gel. The proteins were electrotransferred to polyvinylidene difluoride membranes /U.S. Biochemical), and the membranes were blocked in TBS [10 mM Tris (pH 8.0 ), $150 \mathrm{mM} \mathrm{NaCl}$ ] containing $4 \%$ bovine serum albumin (fraction V; ICN). The membranes were rinsed in TBST (TBS supplemented to contain $0.05 \%$ Tween 20 ) and incubated with the 6C8 hamster anti-human BCL-2 monoclonal antibody (McDonnell et al. 1990) for $2 \mathrm{hr}$. The membranes were rinsed in TBST and exposed to alkaline phosphatase-conjugated rabbit antihamster IgG antibody (U.S. Biochemical). After washing in TBST, the membranes were placed in a buffer containing 100 $\mathrm{mM}$ Tris (pH 9.5), $100 \mathrm{mM} \mathrm{NaCl}, 5 \mathrm{~mm} \mathrm{MgCl}, 330 \mu \mathrm{g}$ of 5-bromo-4-chloro-3-indolyl phosphate/ $\mathrm{ml}$, and $150 \mu \mathrm{g}$ of nitro blue tetrazolium $/ \mathrm{ml}$ (both from Promega) for $2-5 \mathrm{~min}$. The enzymatic reaction was stopped by rinsing the membranes in distilled water. The analysis of cellular phosphotyrosine was performed as described previously (Chen and Rosenberg 1992) except that the CSPD chemiluminescent substrate (Tropix) was used exactly as recommended by the manufacturer.

\section{DNA and RNA analysis}

The procedures for preparation of eukaryotic DNA and RNA have been described previously (Ramakrishnan and Rosenberg 1988). DNAs were digested with the appropriate restriction enzyme, fractionated through $0.8 \%$ agarose gels, and transferred to Nytran membranes (Schleicher \& Schuell). After UV cross-linking, the membranes were hybridized to labeled probes as recommended by the manufacturer. RNAs were fractionated 
through $0.8 \%$ formaldehyde agarose gels and transferred to $\mathrm{Ny}$ tran membranes, and the filters were hybridized as recommended by the manufacturer. Probes were labeled with $\left[\alpha-{ }^{32} \mathrm{P}\right] \mathrm{dCTP}$ (DuPont) by using a random priming kit (Boehringer-Mannheim). The 6.5-kb BamHI-EcoRI fragment from $\mathrm{pECK}$ (Coleclough et al. 1981) was used to examine the / $\mathrm{K}$ region; a 0.4-kb EcoRI fragment containing $V(\lambda 1)-J(\lambda 1)$ was used to examine the Ig $\lambda$ locus; the 0.8 -kb Sau3A fragment from the RS region (Durdik et al. 1984) was used to examine RS; the 0.68-kb PstI fragment from pUCBg700 (Schatz et al. 1989) was used to detect RAG-1; the 2.0-kb EcoRV-NotI fragment from $\mathrm{pR} 2 \mathrm{RSK}^{+} 1$ (Oettinger et al. 1990) was used to detect $R A G-2$; the 0.7-kb EcoRI fragment from pCN3-CYL2 (Matsushime et al. 1991) was used to detect $G_{1}-$ cyclin 2 .

\section{Recombinase assays}

The extrachromosomal recombinase assay was carried out as described previously (Hesse et al. 1987; Ramakrishnan and Rosenberg 1988) and was performed at least twice on all cell lines. Briefly, cells were transfected at the permissive temperature with pJH289 or pJH201 using the DEAE-dextran method. Immediately after the transfection, half of the sample was shifted to the nonpermissive temperature and the other half was maintained at the permissive temperature. After 20-24 hr, extrachromosomal DNA was prepared, treated with DpnI, and maximum efficiency Escherichia coli DH5 $\alpha$ cells (BRL) were transformed. Some of the cells were plated on plates containing ampicillin and others were plated on plates containing ampicillin and chloramphenicol. The recombinase activity was calculated as (number of ampicillin-chloramphenicol-resistant colonies/number of ampicillin-resistant colonies $\mid \times 100$. Plasmids were recovered from randomly selected colonies and digested with HgiAI to confirm that the joining reaction had occurred correctly (Hesse et al. 1987). In all cases, the expected products were recovered.

\section{PCR assay of $\kappa$ rearrangements}

A modification of the PCR method of Schlissel and Baltimore (1989) was used. The $50-\mu$ l reactions contained $2 \mu$ l of template DNA (either cell lysate from $1 \times 10^{4}$ cells or $0.5 \mu \mathrm{g}$ of genomic DNA); $200 \mu \mathrm{M}$ each of TTP, dATP, dGTP, and dCTP; 2.5 $\mathrm{mM} \mathrm{MgCl} 2,100 \mu \mathrm{g} / \mathrm{ml}$ of gelatin, $50 \mathrm{mM} \mathrm{KCl}, 10 \mathrm{mM}$ Tris- $\mathrm{HCl}$ $\left(\mathrm{pH} 8.3\right.$ at $\left.25^{\circ} \mathrm{C}\right), 0.2 \mu \mathrm{M}$ of each primer, and 1 unit of Taq polymerase (Perkin-Elmer Cetus). The $V_{k}$ primer was $5^{\prime}$-GGCTGCAGG/CTTCAGTGGCAGTGGGTC-3'; the $3^{\prime}$ primer, derived from $/ \kappa 5$ and $/ \kappa 5-C_{\kappa}$ intron sequences was $5^{\prime}-\mathrm{CCA}$ AGCTTGTACTTACGTTTCAGCT-3'. Amplifications were performed using a Programmable Thermal Controller (MJ Research, Inc.) for 28 cycles of $1 \mathrm{~min}$ at $94^{\circ} \mathrm{C}, 1.5 \mathrm{~min}$ at $50^{\circ} \mathrm{C}$, and $1.5 \mathrm{~min}$ at $72^{\circ} \mathrm{C}$. After the last cycle, the samples were incubated for $5 \mathrm{~min}$ at $72^{\circ} \mathrm{C}$. A $10-\mu$ l sample of each reaction was fractionated through $2 \%$ agarose gels and blotted to Nytran membranes. The membranes were hybridized to a ${ }^{32} \mathrm{P}$-labeled probe containing the $2.8-\mathrm{kb}$ HindIII insert from $/ \mathrm{k} 1-5$ /Selsing et al. 1984) or a probe containing only the $/ \kappa 5$ region.

\section{Acknowledgments}

We thank Peter Brodeur, John Coffin, Erik Selsing, Harinder Singh, and Henry Wortis for their helpful comments on the manuscript. We are grateful to Stanley Korsemeyer for the $B C L-2$ expression construct and the anti-BCL-2 antibodies, to Charles Sherr for the $G_{1}$ cyclin probe, and to Thereza Imanishi-
Kari and Erik Selsing for many of the probes used for the lightchain loci. We are also grateful to Karen Redlitz for help with some of the experiments and to Karyn Landry and James Ravitz for preparation of the figures. M.S.H. is supported by CA09172 from the National Institutes of Health (NIH). This work was supported by CA24220 from the NIH and IM622A from the American Cancer Society.

The publication costs of this article were defrayed in part by payment of page charges. This article must therefore be hereby marked "advertisement" in accordance with 18 USC section 1734 solely to indicate this fact.

\section{References}

Alt, F.W., N. Rosenberg, V. Enea, E. Siden, and D. Baltimore. 1982. Multiple immunoglobulin heavy-chain gene transcripts in Abelson murine leukemia virus-transformed pre-B cell lines. Mol. Cell. Biol. 2: 386-400.

Alt, F.W., G.D. Yancopoulos, T.K. Blackwell, C. Wood, E. Thomas, M. Boss, R. Coffman, N. Rosenberg, S. Tonegawa, and D. Baltimore. 1984. Ordered rearrangements of immunoglobulin heavy chain variable region segments. EMBO $J$. 3: 1209-1219.

Anderson, S.J., K.M. Abraham, T. Nakayama, A. Singer, and R.M. Perlmutter. 1992. Inhibition of T-cell receptor $\beta$-chain rearrangement by overexpression of the non-receptor protein tyrosine kinase p56 ${ }^{\text {lck }}$. EMBO I. 11: 4877-4886.

Atchison, M.L. and R.P. Perry. 1987. The role of the $k$ enhancer and its binding factor NF- $\mathrm{kB}$ in the developmental regulation of $\kappa$ gene transcription. Cell 48: 121-128.

Chen, J., M. Trounstine, C. Kurahara, F. Young, C.C. Kuo, Y. Xu, J.F. Loring, F.W. Alt, and D. Huszar. 1993. B cell development in mice that lack one or both immunoglobulin $\kappa$ light chain genes. $E M B O$ J. 12: 821-830.

Chen, Y.Y. and N. Rosenberg. 1992. Lymphoid cells transformed by Abelson virus require the v- $a b l$ protein tyrosine kinase only during early G1. Proc. Natl. Acad. Sci. 89: 66836687.

Coleclough, C., R.P. Perry, K. Karjalainen, and M. Weigert. 1981. Aberrant rearrangements contribute significantly to the allelic exclusions of immunoglobulin gene expression. Nature 290: 372-378.

Durdik, J., M.W. Moore, and E. Selsing. 1984. Novel k lightchain gene rearrangements in mouse $\lambda$ light chain producing B lymphocytes. Nature 307: 749-752.

Engelman A. and N. Rosenberg. 1987. Isolation of temperature sensitive Abelson virus mutants by site-directed mutagenesis. Proc. Natl. Acad. Sci. 84: 8021-8025.

1990. Temperature-sensitive mutants of Abelson murine leukemia virus deficient in protein tyrosine kinase activity. J. Virol. 64: 4242-4251.

Engler, P., D. Haasch, C.A. Pinkert, L. Doglio, M. Glymour, R. Brinster, and U. Storb. 1991. A strain-specific modifier on mouse chromosome 4 controls the methylation of independent transgene loci. Cell 65: 939-947.

Engler, P., A. Weng, and U. Storb. 1993. Influence of CpG methylation and target spacing on $\mathrm{V}(\mathrm{D}) \mathrm{J}$ recombination in a transgenic substrate. Mol. Cell. Biol. 13: 571-577.

Graninger, W.B., P.L. Goldman, C.C. Morton, S.J. O'Brien, and S.J. Korsemeyer. 1988. The $\kappa$-deleting element: Germline and rearranged, duplicated and dispersed forms. I. Exp. Med. 167: 488-501.

Green, P.L., D.A. Kaehler, L.M. Bennett, and R. Risser. 1989. Multiple steps are required for the induction of tumors by Abelson murine leukemia virus. J. Virol. 63: 1989-1994. 
Hagman, J., C.M. Rudin, D. Haasch, D. Chaplin, and U. Storb. 1990. A novel enhancer in the immunoglobulin $\lambda$ locus is duplicated and functionally independent of NF-кB. Genes \& Dev. 4: 978-992.

Hardy, R.R., C.E. Carmack, S.A. Shinton, J.D. Kemp, and K. Hayakawa. 1991. Resolution and characterization of pro-B and pre-pro-B cell stages in normal mouse bone marrow. $J$. Exp. Med. 173: 1213-1225.

Hesse, J.E., M.R. Lieber, M. Gellert, and K. Mizuuchi. 1987. Extrachromosomal DNA substrates in pre-B cells undergo inversion or deletion at immunoglobulin V-(D)-J joining signals. Cell 49: 775-783.

Hockenberry, D., G. Nunez, C. Milliman, R.D. Schreiber, and S.J. Korsemeyer. 1990. $B C L-2$ is an inner mitochondrial membrane protein that blocks programmed cell death. $\mathrm{Na}$ ture 348: 334-336.

Jenuwein, T., W.C. Forrester, R.-C. Qui, and R. Grosschedl. 1993. The immunoglobulin $\mu$ enhancer core establishes local factor access in nuclear chromatin independent of transcriptional stimulation. Genes \& Dev. 7: 2016-2032.

Klug, C.A., S.J. Gerety, Y.Y. Chen, N.R. Rice, N. Rosenberg, and H. Singh. 1994. The v-abl tyrosine kinase negatively regulates NF- $\mathrm{kB} / \mathrm{rel}$ and blocks $\kappa$ gene transcription in pre-B lymphocytes. Genes \& Dev. (this issue).

Lenardo, M. and D. Baltimore. 1989. NF-кB: A pleiotropic mediator of inducible and tissue-specific gene control. Cell 58: 227-229.

Lenardo, M., J.W. Pierce, and D. Baltimore. 1987. Protein-binding sites in Ig gene enhancers determine transcriptional activity and inducibility. Science 236: 1573-1577.

Lennon, G.G. and R.P. Perry. 1990. The temporal order of appearance of transcripts from unrearranged and rearranged $\mathrm{Ig}$ genes in murine fetal liver. J. Immunol. 144: 1983-1987.

Lewis, S., N. Rosenberg, F. Alt, and D. Baltimore. 1982. Continuing $\kappa$-gene rearrangement in a cell line transformed by Abelson murine leukemia virus. Cell 30: 807-816.

Lewis, S., A. Gifford, and D. Baltimore. 1984. Joining of $V_{k}$ to $J_{k}$ segments in a retroviral vector introduced into lymphoid cells. Nature 308: $425-428$.

Li, Y.-S., K. Hayakawa, and R.R. Hardy. 1993. The regulated expression of $\mathrm{B}$ lineage associated genes during $\mathrm{B}$ cell differentiation in bone marrow and fetal liver. J. Exp. Med. 178: 951-960.

Lieber, M.R., J.E. Hesse, K. Mizuuchi, and M. Gellert. 1987. Developmental stage specificity of the lymphoid $V(D) /$ recombination activity. Genes \& Dev. 1: 751-761.

Lin, W-C. and S. Desiderio. 1993. Regulation of V(D)/ recombination activator protein RAG-2 by phosphorylation. Science 260: 953-959.

Ma, A., P. Fisher, R. Dildrop, E. Oltz, G. Rathbun, P. Achacoso, A. Stall, and F.W. Alt. 1992. Surface IgM mediated regulation of RAG gene expression in $\mathrm{E} \mu-\mathrm{N}$-myc $\mathrm{B}$ cell lines. $E M B O$ J. 11: $2727-2734$.

Matsushime, H., M.F. Roussel, R.A. Ashmun, and C.J. Sherr. 1991. Colony-stimulating factor 1 regulates novel cyclins during the Gl phase of the cell cycle. Cell 65: 701-713.

McDonnell, T.J., G. Nunez, F.M. Platt, D. Hockenberry, L. London, J.P. McKearn, and S.J. Korsemeyer. 1990. Deregulated Bcl-2 immunoglobulin transgene expands a resting but responsive immunoglobulin $\mathrm{M}$ and $\mathrm{D}$-expressing B-cell population. Mol. Cell. Biol. 10: 1901-1907.

Mombaerts, P., J. Iacomini, R.S. Johnson, K. Herrup, S. Tonegawa, and V.E. Papaioannou. 1992. RAG-1 deficient mice have no mature B and T lymphocytes. Cell 68: 869-877.

Nunez, G., L. London, D. Hockenberry, M. Alexander, J.P. McKearn, and S.J. Korsemeyer. 1990. Deregulated Bcl-2 gene expression selectively prolongs survival of growth factor-deprived hemopoietic cell lines. I. Immunol. 144: 3602-3610.

Oettinger, M.A., D.G. Schatz, C. Gorka, and D. Baltimore. 1990. RAG-1 and RAG-2, adjacent genes that synergistically activate $V(D) J$ recombination. Science 248: $1517-1523$.

Oltz, E.M., F.W. Alt, W.-C. Lin, J. Chen, G. Taccioli, S. Desiderio, and G. Rathbun. 1993. A V(D)J recombinase-inducible B-cell line: Role of transcriptional enhancer elements in directing V(D)J recombination. Mol. Cell. Biol. 13: 6223-6230.

Perlmutter, R.M., S.D. Levin, M.W. Appleby, S.J. Anderson, and J. Alberola-Ila. 1993. Regulation of lymphocyte function by protein phosphorylation. Annu. Rev. Immunol. 11: 451499.

Ramakrishnan, L. and N. Rosenberg. 1988. Novel B-cell precursors blocked at the stage of $\mathrm{DJ}_{\mathrm{H}}$ recombination. Mol. Cell. Biol. 8: 5216-5223.

Reth, M.G., S. Jackson, and F.W. Alt. 1986. $\mathrm{V}_{\mathrm{H}} \mathrm{DJ} \mathrm{H}_{\mathrm{H}}$ formation and $\mathrm{DI}_{\mathrm{H}}$ replacement during pre-B differentiation: Nonrandom usage of gene segments. $E M B O$ J. 5: 2131-2138.

Rolink, A., U. Grawunder, D. Haasner, A. Strasser, and F. Melchers. 1993. Immature surface $\mathrm{Ig}^{+} \mathrm{B}$ cells can continue to rearrange $\kappa$ and $\lambda$ chain loci. J. Exp. Med. 178: 1263-1270.

Rosenberg, N. and O.N. Witte. 1988. The viral and cellular forms of the Abelson ( $a b l)$ oncogene. Adv. Virus Res. 35: 39-81.

Sawyers, C.L., C.T. Denny, and O.N. Witte. 1991. Leukemia and the disruption of normal hematopoiesis. Cell 64: 337350.

Schatz, D.G., M.A. Oettinger, and D. Baltimore. 1989. The V(D)J recombination activating gene, RAG-1. Cell 59: 1035-1048.

Schatz, D.G., M.A. Oettinger, and M.S. Schlissel. 1992. V(D)] recombination: Molecular biology and regulation. Annu. Rev. Immunol. 10: 359-383.

Schlissel, M.S. and D. Baltimore. 1989. Activation of immunoglobulin kappa gene rearrangement correlates with induction of germline kappa gene transcription. Cell 58: 10011007.

Selsing, E., J. Voss, and U. Storb. 1984. Immunoglobulin "remnant" DNA-implications for antibody gene recombination. Nucleic Acids Res. 12: 4229-4246.

Sen, R. and D. Baltimore. 1986. Inducibility of $\kappa$ immunoglobulin enhancer-binding protein NF- $\mathrm{kB}$ by a post-translational mechanism. Cell 58: 1001-1007.

Shapiro, A.M., M.S. Schlissel, D. Baltimore, and A.L. DeFranco. 1993. Stimulation of $\kappa$ light-chain gene rearrangement by the immunoglobulin $\mu$ heavy chain in a pre-B-cell line. Mol. Cell. Biol. 13: 5679-5690.

Shinkai, Y., G. Rathbun, K.P. Lam, E.M. Oltz, V. Stewart, M. Mendelsohn, J. Charron, M. Datta, F. Young, A. Stall, and F.W. Alt. 1992. RAG-2 deficient mice lack mature lymphocytes owing to inability to initiate V(D)J rearrangement. Cell 68: $855-867$.

Takeda, S., Y.-R. Zou, H. Bluethmann, D. Kitamura, U. Muller and K. Rajewsky. 1993. Deletion of the immunoglobulin $\kappa$ chain intron enhancer abolishes $\kappa$ chain gene rearrangement in cis but not $\lambda$ chain gene rearrangement in trans. EMBO \% 12: 2329-2336.

Vaux, D.L., S. Cory, and J.M. Adams. 1988. Bcl-2 gene promotes haemopoietic cell survival and cooperates with c-myc to immortalize pre-B cells. Nature 335: 440-442.

Yancopoulos, G.D. and F.W. Alt. 1985. Developmentally controlled and tissue-specific expression of unrearranged $\mathrm{V}_{\mathrm{H}}$ gene segments. Cell 40: 271-281.

Zou, Y.-R., S. Takeda, and K. Rajewksy. 1993. Gene targeting in the Igא locus: Efficient generation of $\lambda$ chain-expressing $B$ cells, independent of rearrangements in Igк. EMBO $/$. 12: $811-820$. 


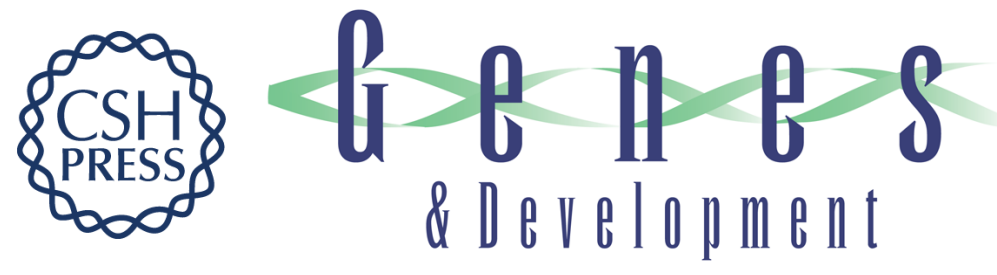

\section{An active $v$-abl protein tyrosine kinase blocks immunoglobulin light-chain gene rearrangement.}

Y Y Chen, L C Wang, M S Huang, et al.

Genes Dev. 1994, 8:

Access the most recent version at doi:10.1101/gad.8.6.688

References This article cites 51 articles, 22 of which can be accessed free at:

http://genesdev.cshlp.org/content/8/6/688.full.html\#ref-list-1

License

Email Alerting Receive free email alerts when new articles cite this article - sign up in the box at the top Service right corner of the article or click here.

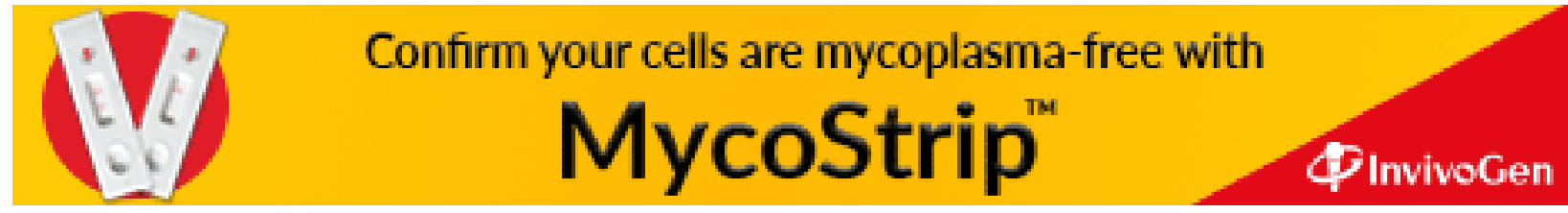

